\title{
Do justice to court interpreters in South Africa
}

\author{
Samuel Lebese \\ Department of Linguistics and Modern Languages, University of South Africa, South Africa \\ Email: lebessj@unisa.ac.za
}

\begin{abstract}
Many countries have developed statutory provisions governing norms and standards of practice (NSPs) for court interpreters. However, in South Africa, in the case of State versus Naidoo (1962:631), Judge Williamson states that "in relation to the courts of this country, there appears to be no statutory provision, Rule of Court or regulation governing the position of interpreters". If Judge Williamson's statement is true, court interpreters could be perceived as working without proper guidance from a statute containing NSPs for court interpreters. This situation might result in court interpreters working according to their own personal preferences, each creating and abiding by his or her own NSPs. In turn, this could lead to poor interpreting practices, as there would be no application of common NSPs which court interpreters are to follow and for which they need to be held accountable. The aim of this study is to investigate whether the statement by Judge Williamson is true, and if so, how the lack of NSPs for court interpreters could affect their work. This aim was achieved by examining the Personnel Administration Standard for Court Interpreters, contained in the Public Service Code, which relates to the employment of court interpreters in the Department of Justice and Constitutional Development of South Africa; the Magistrates' Court Act 44 of 1944 (as amended); the Oath of Office of Interpreters in terms of Rule 68 (1) of the Magistrates' Court Act 44 of 1944 (as amended); the Constitution of the Republic of South Africa, Act 108 of 1996 (as amended), and extracts from some case studies (Lebese 2011, 2013). The study revealed that the four documents do not make any reference to NSPs for court interpreters. The study concludes with a recommendation for the need of a statute governing court-interpreting issues in the broadest sense, including NSPs.
\end{abstract}

Keywords: court interpreters, legislation, norms, standards of practice

\section{Introduction}

A fair criminal justice system would ensure that both the accused and the witness understand the courtroom proceedings, and that both parties are also understood by the court. This fairness cannot be attainable in instances where court interpreters cannot be provided for court participants who do not speak or understand the language used during court proceedings. Keratsa (2005) views a trial in a court of law as a battle fought with words, and that such battles are fought by people who cannot speak and understand the legal language of the setting. Therefore, the presence of an interpreter, as a mediator and a necessary contributor in 
overcoming language barriers and ensuring communication, is considered essential (Keratsa 2005). However, for court interpreters to be able to carry out their duties competently, they need to be guided by some sort of legislation that deals with issues of court interpreting, and that clearly defines the norms and standards of practice (NSPs) to be followed by all court interpreters. These NSPs serve as a set of rules that guide court interpreters in their task of interpreting during trials.

Many countries have developed NSPs to guide court interpreters in carrying out their duties. These NSPs vary from country to country but all have one common goal - to regulate and guide the function of court interpreters. For example, Hewitt (1995:199) states that in the US, the Model Code of Professional Responsibility for Interpreters in the Judiciary was developed by the National Center for States Courts, and frames the role of the court interpreter in the following manner:

Many persons who come before the courts are partially or completely excluded from full participation in the proceedings due to limited English proficiency or a speech or hearing impairment. It is essential that the resulting communication barrier be removed, as far as possible, so that these persons are placed in the same position as similarly situated persons for whom there is no such barrier. As officers of the court, interpreters help ensure that such persons may enjoy equal access to justice, and that court proceedings and court support services function efficiently and effectively. Interpreters are highly skilled professionals who fulfil an essential role in the administration of justice.

Toury (1980) observes that norms play a central role in Descriptive Translation Studies (DTS) as they determine the type and extent of equivalence manifested by actual translations. In this study, the concept of 'translation' is used in its broadest sense and encompasses the concept of 'interpreting'. "Equivalence" refers to the relationship, of whatever type and extent, between a translation and its source text (Toury 1980). In instances of interpreting, equivalence refers to the relationship between the message of the target and the source language.

According to Malmkjaer (2005), adherence to or deviation from norms can incur approval or sanction of various kinds, including positive or negative criticism. These norms function as various types of sociocultural constraint on human behaviour (Meylaerts 2008). Court interpreting involves sociocultural aspects as court interpreters facilitate communication between people who speak different languages; as a result, norms are relevant. This study regards norms as the criteria according to which actual instances of interpreting are evaluated as acceptable or unacceptable, between the expectation regarding the relation between the source-and target-language message. This evaluation rests on a set of rules that guides court interpreters in fulfilling their task. Norms are therefore a tool that is used to gauge the acceptability of the interpreting task.

However, in the case of State versus Naidoo (1962:631), Judge Williamson mentions that "in relation to the courts of this country, there appears to be no statutory provision, Rule of Court or regulation governing the position of interpreters". If Judge Williamson's statement is true, 
court interpreters would then in essence be working without proper guidance from a statute containing NSPs for court interpreters. This situation might lead to court interpreters working according to their own personal preferences, each creating and abiding by his or her own NSPs. This could, in turn, lead to poor interpreting practices as there would be no application of common NSPs which court interpreters are to follow and for which they need to be held accountable. Mikkelson (1996) observes that interpreting is characterised by a lack of standards for training and practice, among other things. Du Plessis (1997:1) holds the same view and mentions that "interpreting may be a clearly defined, well-established profession operating within a structured context in many countries of the world, but in South Africa the profession still has a long way to go to attain the same status".

If NSPs do not exist, court interpreters themselves have to deal with the controversies surrounding their duties and position. The situation might be that, while interpreters perform their duties from day to day, they are "constantly making decisions and solving problems by navigating between the Scylla of slavish, which is the literal interpretation, and the Charybdis of free translation that distorts meaning and thereby perverts justice" (Mikkelson 2008:2).

The aim of this study is to investigate whether there is any statute governing the NSPs for court interpreters in South Africa, and if so, to what extent. If no such statute exists, the aim will be to investigate how this deficit affects the work of court interpreters. Four legal documents will be examined: the Personnel Administration Standard for Court Interpreters (PAS), contained in the Public Service Code, which relates to the employment of court interpreters in the Department of Justice and Constitutional Development of South Africa; the Magistrates' Court Act 44 of 1944 (as amended); the Oath of Office of Interpreters in terms of Rule 68 (1) of the Magistrates' Court Act 44 of 1944 (as amended), and the Constitution of the Republic of South Africa, Act 108 of 1996 (as amended), as well as several extracts from case studies (see Lebese $2011,2013)$. The documents under investigation relate to court interpreters and are currently in use and legally recognised. The case studies are relevant for this study as they allow us to determine whether or not court interpreters are guided by any norms when they interpret, and whether they abide by these norms. If it is found that they are not guided by any norms, the aim is then to investigate how interpreters carry out their task of interpreting, and whether or not the lack of NSPs affects this task, as well as to what extent this effect is felt. The study aims to shed more light on the importance of NSPs for court interpreters, and how these NSPs can lead to better interpreting. The study concludes with a recommendation for the need of a statute governing court-interpreting issues (in the broadest sense) including NSPs.

\section{Methodology}

This study follows a qualitative research method and the DTS theoretical framework. The relevance of the qualitative method in research methodology and the DTS framework to this study lies in the fact that court interpreting takes place in real courtroom situations where court participants are present during proceedings. According to Toury (1980:80), translation practices are observational facts. Because court interpreting takes place in real world situations, court interpreting practices are therefore also observational facts. Hillinger and Leu (1994) mention that the qualitative research method in interpreting studies explores how language, power and history shape human views of reality, truth and knowledge, and aims to discover multiple realities. Shank (2002) holds the same view and uses two metaphors to describe the qualitative research method. The first metaphor is that of a window, as the researcher looks through a 
metaphorical window to get an accurate view of a subject. The second metaphor is that of a lantern, which suggests that this method sheds light on dark areas. Gall, Borg and Gall (1996) mention that the qualitative research method is grounded in the assumption that individuals construct social reality in the form of meanings and interpretations, while Meulenberg-Buskens (1993) views it as a method in which the researcher tries to relate the topic of study directly to phenomena in reality.

The court proceedings are regulated by rules and regulations of administration of justice contained in pieces of legislation, such as the Magistrates' Court Act 44 of 1944 (as amended). As previously mentioned, this study investigates four legal documents relating to issues of court interpreters, with the aim of obtaining an accurate view of what is contained in these documents regarding these issues. In doing so, the study aims to discover multiple realities and reveal the truth as to whether or not these legal documents contain any guidance for court interpreters in respect of NSPs. In addition, extracts from court proceedings will be analysed to observe how court interpreters carry out their task of interpreting by relating directly to the facts observable during the court proceedings.

\section{The importance of norms and standards of practice}

Before discussing the four legal documents mentioned above, it is imperative to examine how scholars view the importance of translation NSPs, and to show how relevant these NSPs are to court interpreting. Schäffner (1998) maintains that the concept of 'norms' is one which has been used differently within the field of Translation Studies, and of which the value was asserted strongly as well as being called into question. She maintains that research in this field has been concerned with the description of actual translation, and the formulation of general principles and practical translations. As such, Schäffner is of the opinion that norms play an important role with regard to these aspects since these descriptions, as mentioned above, are related to assumptions and expectations about the correctness or appropriateness of translations. According to Schäffner (1998), Bartsch (1987) applied the concept of 'norms' to linguistics, and differentiated between product norms and production norms. According to Bartsch (1987), product norms concern the correctness regarding the language system, and production norms concern the methods and strategies by which the correct product can be achieved.

With regard to what has been stated in the paragraph above, norms are relevant to court interpreting as interpreting is a process of interaction between people and must therefore be regulated in one way or another. One of the ways of doing this is by introducing norms to regulate the process of interpreting itself, and also to regulate the conduct of practitioners who offer the service. According to Schäffner (1998), the concept of 'norms' plays an important role in linguistic approaches to translation as it is concerned with the linguistic norms of the two languages. Firstly, norms relate to how utterances and texts, that are correct according to the respective rules and norms, are produced. Secondly, they relate to the relations and regularities between the two linguistic systems that were discovered on the basis of contrastive analyses, which were then translated into guidelines or rules for the translator, mostly with prescriptive intent.

The importance of NSPs in relation to court interpreting lies in the fact that court interpreting involves sociocultural factors and, as a result, court interpreters have to follow certain norms and meet certain criteria in order to be able to carry out their task as expected and in an 
acceptable manner. These criteria involve the standards of practice which entail the requirement to be admitted or appointed as a court interpreter. For instance, people who may be appointed as court interpreters could be those who possess certain qualifications relating to interpreting, as well as certain basic skills in interpreting or communication. People who meet these criteria can then be recruited and trained to become court interpreters as they have certain foundations upon which interpreting skills can be built. The expectation in this instance involves how the source-language speaker wants his or her message to be sent across to the target-language speaker in a manner that will achieve the aims of the message. For example, if the sourcelanguage speaker sends a message that will prompt the target-language speaker to respond, the source-language speaker would expect a response from the target-language speaker.

On the other hand, the target-language speaker has to acknowledge the interpreted version of the source language. This means that the version that the target-language speaker hears from the court interpreter, which is what the interpreter says was said by the source-language speaker, must be produced according to the target-language speaker's existing linguistic systems and features. In other words, the language systems have to be those used by such speakers in their natural sense, i.e. the normal way of speaking that particular language, without any stiltedness features which will make the language unacceptable. Therefore, norms play an important part in the transfer of the message as they guide court interpreters in the production of utterances that are correct and acceptable according to the linguistic systems and regularities of the languages concerned. This can be determined by way of contrastive analysis, where the utterances of both the source and target language are compared to see whether the production (i.e. the interpretation) is correct and accurately represents the source language.

\section{Discussion of norms}

Some translation scholars (cf. Schäffner 1998; Hermans 1996, 2013; Chesterman 1997) are of the view that the concept of 'norms' was first applied in the context of translation studies by Toury, who argued that translation, in its sociocultural dimension, is subject to constraints of several types and to varying degrees. Toury (1995) observes that, in terms of their potency, sociocultural constraints have been described along a scale, with general, relatively absolute rules on the one end, and pure idiosyncrasies on the other. Between these two poles lies a vast middle-ground occupied by intersubjective factors such as commonly designated norms. These norms form a graded continuum along the scale; some are stronger and more stringent, while others are weaker and almost idiosyncratic (Toury 1995).

Toury (1995:14) defines norms as "the translation of general values or ideas shared by a community - as to what is right and wrong, adequate and inadequate - into performance instructions appropriate for and applicable to particular situations". These norms are sociocultural constraints specific to a culture, society and time, and an individual acquires these norms through the general processes of education and socialisation (Toury 1995). He uses the term "norm" as a descriptive analytical category to be studied through the behaviour selected on a regular basis by translators in a given sociohistorical context. In his view, "translatorship", first and foremost, plays a social role through the fulfilment of a function allotted by a community to the activity, its practitioners and/or products, in a way which is deemed appropriate in its own terms of reference. The acquisition of a set of norms for determining the suitability of that kind of behaviour, and for manoeuvring between all the factors which may constrain it, is therefore a prerequisite for becoming a translator within a cultural environment 
(Duflou 2007). For Toury (1995), translation is an activity governed by norms which determine the equivalence manifested in actual translations.

Toury (1995) differentiates between three kinds of norms operating at different stages. The first is what he calls "initial norms", which are general choices made by translators. Translators can subject themselves to the norms realised in a source text (ST), or to those of the target culture or language. In the case of the former, the target text (TT) will then be adequate; if the norms of the target culture prevail, then the TT will be acceptable. The second kind of norm is what Toury (1995) calls "preliminary norms". These refer to the translation policy that determines the selection of texts for translation in a specific language, culture and time. Finally, "operational norms" describe the presentation and linguistic matter of the TT. These norms relate to issues of completeness regarding the TT.

Hermans (1996) holds the same view and states that norms, like rules and conventions, are psychological and social entities, and have a socially regulatory function as they constitute an important factor in the interaction between people. Norms help to bring about the coordination required for continued coexistence with others. By doing so, they safeguard the conditions of the collective sphere as they mediate between this entity and the individual, as well as between an individual's intentions, choices and actions, and the collectively held beliefs, values and preferences. Norms contribute to the stability and uncertainty that spring from an inability to control time and predict the actions of fellow human beings. The reduction of contingency brought about by norms is a matter of generalising from past experience, and making reasonably reliable, more-or-less prescriptive projections concerning similar types of situations in the future (Hermans 1996). Hermans (1996) further states that norms are prescriptive rules which have a normative semantic load, and are used to guide, control or change the behaviour of agents with decision-making capacities. According to him, norms tell individual members of a community not just how everyone else expects them to behave in a given situation, but how they ought to behave. He also states that norms imply that the community has agreed that a certain behaviour or action should be adopted as proper or correct (Hermans 1996).

In his discussion of norms, Chesterman (1997) notes that all norms exert a prescriptive pressure; he thus proposes another set of norms covering Toury's initial and operational norms. These include product or expectancy norms and process or professional norms. Product or expectancy norms are established by the expectations of readers of a translation (of a given type) concerning what a translation (of this type) should be like. Chesterman raises two important issues regarding expectancy norms: firstly, they allow evaluative judgements about translations, since readers have a notion of what is an "appropriate" or "acceptable" translation of the specific text variety, and will approve of a translator who conforms to these expectations. Secondly, these norms are sometimes "validated by a norm-authority of some kind" (Chesterman 1997). For example, a translation should meet the target-language criteria of readability and fluency (Munday 2008:117).

Professional norms, on the other hand, regulate the translation process itself, and are subordinate to and determined by expectancy norms. Chesterman (1997) proposes three kinds of professional norms: the first is the accountability norm, which is an ethical norm dealing with professional standards of integrity and thoroughness. It means that the translator accepts responsibility for the work produced for the commissioner and reader. The second is the communication or social norm. Here, the translator or the communication expert works to 
ensure maximum communication between the parties. Finally, the relation or linguistic norm deals with the relation between the ST and TT. Chesterman (1997) observes that professional norms are validated partly by norm authorities, such as professionals and professional bodies, and partly by their very existence.

The three kinds of professional norms proposed by Chesterman (1997) are also applicable to court interpreters. The accountability norm ensures that court interpreters accept responsibility for their product - the rendered interpreting message passed on to the listener who receives that interpretation. The communication norm ensures that the listener receives an interpretation that is clear and can be understood without difficulty or misunderstanding. Finally, the relation norm ensures that the interpretation received by the listener matches the source-language message.

The discussion above indicates how translation is subject to and should be governed by norms. Hermans (2013) is of the view that the importance of the concept of 'norms' in translation is that it allows for a revision of the traditional notion of what constitutes a correct translation; considered from a norm-theoretical point of view, correctness in translation cannot be predetermined but is a matter of compliance with prevailing norms of translation. Toury (1995) argued that norms in translation give substance to equivalence and, in his view, if a text is accepted as a translation, it follows axiomatically that the relation of equivalence between the translation and its original stands, as norms determine the concrete shape of that equivalence relation in specific instances.

On the other hand, interpreting, which also falls within the broad definition of translation, is bound to be affected by norms as, like translation, interpreting is a sociocultural activity which involves communication between two or more people (Toury 1995). Toury's argument is based on his definition of norms as "the translation of general values or ideas shared by a community - as to what is right and wrong, adequate and inadequate - into performance instructions appropriate for and applicable to particular situations" (Toury 1995:14). Schjoldager (1995, in Pöchhacker and Shlesinger 2002) confirms this notion and states that interpreting as a behavioural activity must also be governed by norms as interpreters need these norms to help them select appropriate solutions to the problems they encounter. Mikkelson (2008) observes that most of the norms governing court interpreters in different countries emphasise the requirement for messages to be interpreted faithfully and completely. She quotes an example of Canon 1 of the US Model Code, which states that:

[i]nterpreters shall render a complete and accurate interpretation or sight interpretation, without altering, omitting, or adding anything to what is stated or written, and without explanation.

(Mikkelson 2008:1)

\section{Discussion of standards of practice}

Many countries have laid down standards of practice for court interpreters or a code of ethics stipulated by law and by which all court interpreters employed in those countries must abide. In the US, the interpreters' code originated with the Court Interpreters Act of 1978 at a time when ad hoc interpreters were the norm and administrators sought to suppress "nonprofessional" behaviour (Camayd-Freixas 2011). 
Meulenbergs, Verpeet, Schotsmans and Gastmans (2004) define "standards of practice" as a set of professional guidelines grounded in a code of ethics which encompasses related values and principles. These standards are often used to identify desired qualifications, specify expectations and evaluate the execution of required skills within a given profession. However, these standards of practice function externally as guiding principles for interpreters, unlike norms which function internally (i.e. during the process of interpreting). Furthermore, these standards of practice are more like a code of conduct which interpreters must follow, from the acceptance of the interpreting assignment until the finalisation thereof.

Tseng (1992), in his model of the professionalisation of court interpreting, refers to standards of practice as a code of ethics. He observes that the enforcement of a code of ethics is crucial because it functions externally as one of the bargaining chips to earn public interest, and internally as an indispensable tool for internal control.

In Denmark, the Danish Administration of Justice Act XI of 1994, as amended by Legal Notice 425 of 2007, was proclaimed in 1994. Section 149(1) of this Act stipulates, among other things, the language of the courts, the provision of court interpreters for those who cannot speak the language of the court, and the requirements that court interpreters must meet in order to interpret in court.

In the US, the most evolved code in the profession of court interpreting is the Massachusetts Code of Professional Conduct for Court Interpreters of the Trial Court. The key to the success of this code is that it begins by precisely setting out its guiding principles. These standards seek to assure meaningful access, protect constitutional rights, and ensure due process as well as equal protection of the law for non-English-speakers (González, Vasquez and Mikkelson 1991).

\section{Legislation on court interpreting in other countries}

In many countries, efforts to address controversies surrounding issues of court interpreting have been made by legal professions and professional bodies of court interpreting. In the US, there has been a significant increase in the number of states that have enacted legislation to set standards for court interpreters and that have joined the Consortium of the National Center for the State Courts (Mikkelson 2008). For example, the Court Interpreters Act of 1978 (amended in 1988) mandates the development of a national certification examination at the federal level to test interpreters' linguistic and interpreting skills, which is provided for the assessment of certified interpreters in judicial proceedings instituted by the US (De Jongh 2008). On 26 June 2006, the Florida Legislature authorised the Supreme Court of Florida to establish minimum standards and procedures for the qualification, certification, professional conduct, discipline, and training of court interpreters. The Florida Court Interpreter Certification was implemented on 6 May 2008 (De Jongh 2008).

The National Association of Judiciary Interpreters and Translators (NAJIT), a well-known association of interpreters and translators in the US, was born out of legislation. NAJIT has a code of ethics and professional responsibilities with which all its members are bound to comply. The code came into existence because of the trust that is placed in court interpreters, and the magnitude of their responsibility necessitates high, uniform ethical standards that will guide and protect court interpreters in the course of their duties as well as uphold the standards of the profession as a whole. This code deals with issues of accuracy, impartiality and conflict of 
interests, confidentiality, limitations of practice, protocol and demeanour, maintenance and improvement of skills and knowledge, accurate representation of credentials, and impediments to compliance (Mikkelson 2008).

Standards of practice for court interpreters have been re-examined with a view to making them reflect more accurately what interpreters are actually doing or should be doing in the field, and to provide more meaningful guidance for practitioners. Some of these associations have the support of the legal professions and other legal departments in the US (Mikkelson 2008).

\section{Data analysis}

The data comprise legal documents dealing with aspects of court interpreting; these include the Personnel Administration Standard for Court Interpreters (PAS), contained in the Public Service Code; the Magistrates' Court Act 44 of 1944 (as amended); the Oath of Office of Interpreters in terms of Rule 68 (1) of the Magistrates' Court Act 44 of 1944 (as amended); the Constitution of the Republic of South Africa, Act 108 of 1996 (as amended), and the extracts from court proceedings (Lebese 2011, 2013). The legal documents will be investigated in order to ascertain whether the statement by Judge Williamson (see section 1), in the case of State versus Naidoo (1962), is true. Extracts from court proceedings are analysed to investigate whether there are any norms existing for court interpreters, and if they are being followed during interpreting.

\subsection{South African legal documents relating to court interpreters}

\subsubsection{The Personnel Administration Standard for Court Interpreters}

The PAS is a document contained in the Public Service Code which deals with matters relating to court interpreters. It came into effect on 10 June 1994 and is the generally prevailing measure regulating the employment, post-classification, educational qualifications, promotions and salaries of court interpreters employed in the Department of Justice and Constitutional Development of South Africa. This document is applicable to personnel who interpret during court sessions. Annexure A of the PAS deals with the prescribed job contents of the occupational class of court interpreters. In the introduction, this document states the following:

The main object of job contents description is to define, by means of basic job description, posts levels for the purpose of the creation of posts, and not necessarily to establish detailed duty sheets. Departments must still compile duty sheets for separate posts and keep it up to date complementary to job contents descriptions, for purpose of application in practice.

(PAS:11)

Part 1 of the PAS reads as follows:

POST CLASS COURT INTERPRETER GRADE I/II AND SENIOR COURT INTERPRETER GRADE I/II/III:

1. Verrig tolkwerk. // Do interpretation work. 
2. Verrig elementêre klerklike werk wanneer hof nie in setting is nie. // Do elementary work when the court is not in session.

3. Skryf hofboeke op. // Keep records up to date.

4. Maak opname-apparaat skoon. // Clean recording equipment.

(PAS:10)

Contrary to the Court Interpreters Act in countries like the US, which has laid down standards of practice for court interpreters, the PAS, as the generally prevailing measure regulating the abovementioned issues regarding court interpreters in South Africa, does not mention anything regarding NSPs for court interpreters.

\subsubsection{The Magistrates' Court Act 44 of 1944 (as amended)}

This Act (henceforth the Magistrates' Court Act) came into effect in 1994, and has been amended from time to time as the need arose. Its purpose is, in part, to regulate the proceedings in magistrates' courts as it defines and explains the roles of court officials (e.g. magistrates, prosecutors, lawyers and advocates) during trials. Court interpreters are also involved in courtroom proceedings if they offer their services to any court participant who is not in a position to follow proceedings due to the latter being unable to speak or understand the language used during those proceedings. Such persons can be an accused, a witness or even a lawyer or advocate representing either the accused or the witness because s/he has been given a watching brief. Because of their involvement in these proceedings, interpreters must be classified as court officials unless there is legislation defining or classifying them differently. Section 6(2) of the Magistrates' Court Act states:

If in a criminal case, evidence is given in a language with which the accused is not in the opinion of the court sufficiently conversant, a competent interpreter shall be called by the court in order to translate such evidence into the language with which the accused professes or appears to the court to be sufficiently conversant, irrespective of whether the language in which the evidence is given is one of the official languages or of whether the representative of the accused is conversant with the language used in evidence.

(Baker, Erasmus and Farlam 1980:10)

The Magistrates' Court Act, however, does not address the issues of NSPs for court interpreters. It would have been expected of the Act to explicitly mention these two issues as they form the core in the function of court interpreters. This would have been the correct way of guiding and also holding court interpreters accountable in carrying out their task.

\subsubsection{The Oath of Office of Interpreters}

In terms of Rule 68 (1) of the Magistrates' Court Act 44 of 1944 (as amended), every interpreter is required to take an oath or make an affirmation, in writing, before a judicial officer. The oath reads as follows: 
I, ........................, (full name) do hereby swear/truly affirm that whenever I may be called upon to perform the functions of an interpreter in any proceedings in any magistrate's court I shall truly and correctly to the best of my knowledge and ability interpret from the language I may be called upon to interpret into an official language of the Republic of South Africa and vice versa.

In terms of this rule, court interpreters are therefore required to take an oath before they start to interpret in any court of law. However, the oath does not stipulate any guidelines, in the form of norms, which will inform court interpreters of the expectations they have to meet when performing their task of interpreting.

\subsubsection{The Constitution of the Republic of South Africa, Act 108 of 1996 (as amended)}

The Constitution is regarded as the supreme law of the country and contains the Bill of Rights, a cornerstone of democracy in South Africa which the state must respect, protect, promote and fulfil. Section 6 of the Constitution embraces multilingualism through the promotion of all 11 official languages. Thus, it protects and promotes the use of the indigenous languages in Government and other spheres of the state. The Bill of Rights provides for language rights for arrested, detained, and accused persons. Section 34 of the Constitution deals with access to courts, and states that everyone has the right to have any dispute, which can be resolved by the application of law, decided in a fair public hearing before a court or, where appropriate, another independent and impartial tribunal or forum. With regard to the issue of language rights in South Africa, there is the demand for language facilitators who can facilitate communication between individuals who do not share the same language. This situation also applies to proceedings in a court of law as English and Afrikaans are the only languages still used as languages of the record. Hlophe (2004) observes that the position explained above poses a challenge for those South Africans whose home language is neither English nor Afrikaans, meaning that there will be a risk of injustice in the South African courts. Hlophe (2004) further states that the continued existence of these linguistic and cultural barriers represents a genuine threat to the effective dispensation of justice in our South African courts. Therefore, interpreters and translators play a crucial role in bridging the communication gap between courtroom participants who do not share the same language. In a courtroom setting, court interpreters have to deal with sociolinguistic issues because of the involvement of the different languages (Hlophe 2004). Court interpreters therefore need some guidelines to help them carry out their task in an acceptable, correct and expected manner. These guidelines would also serve as a protective measure of linguistic rights of those for whom court interpreters interpret.

Section 35 of the Constitution deals with the rights of arrested, detained and accused persons, and Subsection $(3)(\mathrm{k})$ states:

Every accused person has a right to a fair trial, which includes the right to be tried in a language that the accused person understands or, if that is not practicable, to have the proceedings interpreted in that language. 
Section 35(4) states that whenever information is to be given to a person, that information must be given in a language that the person understands. Although the Constitution discusses the linguistic rights of individuals (cf. Sections 6, 34 and 35), it does not mention matters relating to court interpreters, such as the NSPs that court interpreters have to follow in fulfilment of their task.

\subsubsection{Case studies}

This section contains the analysis of extracts from transcribed court proceedings taken from Lebese $(2011,2013)$. Although the extracts were used by Lebese $(2011,2013)$ to investigate whether or not the role of South African court interpreters was defined, they are still relevant for the present study. The relevance lies in the fact that the concept of 'role' is determined by certain NSPs. The present study investigates the role played by court interpreters during trials to ascertain whether they are guided by NSPs in carrying out their task. The languages used during the proceedings were English and Setswana.

The following symbols are used in Tables 1-3 which contain the data extracted from Lebese's (2011, 2013) case studies:

- $\quad+$ represents the additions made.

- - represents the omissions made.

- represents non-interpretation.

- TT represents the target text.

- ST represents the source text.

- Backtr represents a back-translation.

\subsubsection{Case study 1}

In this case, the accused, an adult male who was represented by an advocate, was charged with an offence of reckless or negligent driving. What appears in Table 1 is what transpired during the proceedings.

Table 1. Extract for case study 1 (Lebese 2011:353-354)

\begin{tabular}{|c|c|c|}
\hline Magistrate/Prosecutor/Lawyer/Advocate & Interpreter & Accused/Witness \\
\hline $\begin{array}{l}\text { P: As the court pleases your worship. The } \\
\text { charge against the accused is reckless or } \\
\text { negligent driving. In that on or about the } 16^{\text {th }} \\
\text { of June } 2007 \text {, and on Letlhabile-Maboloka } \\
\text { road, a public road in the district of Brits, the } \\
\text { accused did drive a vehicle to wit, Nissan } \\
\text { Sentra with registration number CHC } 680 \\
\text { NW, recklessly or negligently. [ST1] }\end{array}$ & $\begin{array}{l}\text { A o thaloganya se ne o se bolellwa } \\
\text { gore ka di } 16 \text { tsa June } 2007 \text {, mo tseleng } \\
\text { ya Letlhabile-Maboloka, o draivile } \\
\text { koloi ya Nissan Sentra ka botlhaswa le } \\
\text { go se thokomele. O a thaloganya? } \\
\text { [TT1] }\end{array}$ & \\
\hline
\end{tabular}




\begin{tabular}{|c|c|c|}
\hline Magistrate/Prosecutor/Lawyer/Advocate & Interpreter & Accused/Witness \\
\hline & $\begin{array}{l}\text { Backtr: (- As the court pleases your } \\
\text { worship. The charge against the } \\
\text { accused is reckless or negligent } \\
\text { driving.) ( }+ \text { Do you understand what } \\
\text { you were told that) on the } 16^{\text {th }} \text { of June } \\
2007 \text {, (- and) on Letlhabile-Maboloka } \\
\text { road (- a public road in the district of } \\
\text { Brits) you drove a Nissan Sentra } \\
\text { vehicle, recklessly and negligently. (+ } \\
\text { Do you understand?) }\end{array}$ & \\
\hline & $\begin{array}{l}\text { (-Yes) (+ I do understand the charge.) } \\
\text { [TT2] }\end{array}$ & $\begin{array}{l}\text { A: Ee. [ST2] } \\
\text { Backtr: Yes. }\end{array}$ \\
\hline M: And how do you plead? [ST3] & $\begin{array}{l}\text { O ipona molato kampo ga o ipone } \\
\text { molato? [TT3] } \\
\text { Backtr: Do you plead guilty or not } \\
\text { guilty? }\end{array}$ & \\
\hline & (- I plead) not guilty. [TT4] & $\begin{array}{l}\text { A: Ga ke ipone } \\
\text { molato. [ST4] } \\
\text { Backtr: I plead not } \\
\text { guilty. }\end{array}$ \\
\hline $\begin{array}{l}\text { Adv: As the court pleases your worship. The } \\
\text { plea is in accordance with my instructions and } \\
\text { furthermore the accused elects to exercise his } \\
\text { rights to remain silent. [ST5] }\end{array}$ & & \\
\hline $\begin{array}{l}\text { M: To shorten the proceedings, does the } \\
\text { accused admit that on the } 16^{\text {th }} \text { of June } 2007 \text {, on } \\
\text { Letlhabile-Maboloka road, he drove a Nissan } \\
\text { Sentra with registration number CHC } 680 \\
\text { NW? [ST6] }\end{array}$ & & \\
\hline Adv: Indeed so, your worship. [ST7] & & \\
\hline
\end{tabular}




\begin{tabular}{|l|l|l|}
\hline Magistrate/Prosecutor/Lawyer/Advocate & \multicolumn{1}{|c|}{ Interpreter } & Accused/Witness \\
\hline M: Do you confirm, sir? [ST8] & $\begin{array}{l}\text { O a netefatsa gore ka letsatsi le o ne o } \\
\text { driva koloi ya Nissan Sentra, ya } \\
\text { registration number CHC 680 NW? } \\
\text { [TT8] } \\
\text { Backtr: Do you confirm (- sir) (+ that } \\
\text { on that day you were driving Nissan } \\
\text { Sentra vehicle with registration } \\
\text { number CHC 680 NW?) }\end{array}$ & $\begin{array}{l}\text { A: Ee. [ST9] } \\
\text { (- Yes.) (+ Correct, I confirm.) [TT9] }\end{array}$ \\
\hline
\end{tabular}

In this case, after the court interpreter interpreted the charge for the accused, she asked him the following question in TT1: "O a thaloganya?" ('Do you understand?'). According to Erasmus (2009), it is the duty of the presiding officer to direct any procedural questions to the accused, from the beginning to the end of the trial. In this instance, it should have been the presiding officer who asked the accused whether he understood the charge, and not the interpreter.

According to Mikkelson (2008:1), the task of an interpreter is to render a complete and accurate interpretation, without altering, omitting or adding anything to what is stated or written, and without explanation. González et al. (1991) hold the same view and state that the interpreter shall render a complete and accurate interpretation. In TT1, the interpreter has made further additions, indicated in the table by + , which were not present in ST1. Furthermore, in TT2, TT4, TT8 and TT9, the interpreter omitted words (indicated by -). The interpreter did not interpret the communication between the magistrate and the advocate in ST5, ST6 and ST7.

The questions to be asked in this case are the following: firstly, is the interpreter guided by any statute regarding her task and, if so, why did she carry out the task of the magistrate? Secondly, why did she make additions, which is contrary to what Mikkelson (2008:1) states? Thirdly, why did the interpreter omit words as indicated in TT2, TT4, TT8 and TT9? Lastly, why did the interpreter not interpret the communication between the magistrate and the advocate in ST5, ST6 and ST7? These questions will be answered during the discussion of the findings.

\subsubsection{Case study 2}

In the following case, the accused was an unrepresented male charged with an offence of assault with intent to do grievous bodily harm. 
Table 2. Extract for case study 2 (Lebese 2011:354-355)

\begin{tabular}{|c|c|c|}
\hline Magistrate/Prosecutor/Lawyer/Advocate & Interpreter & Accused/Witness \\
\hline \multirow[t]{3}{*}{$\begin{array}{l}\text { P: The charge against the accused is that on or } \\
\text { about the } 28^{\text {th }} \text { day of November } 2009 \text {, at or near } \\
\text { Nkele's tavern at Majakaneng, in the district of } \\
\text { Brits, the accused did unlawfully assault the } \\
\text { complainant, an adult male person, by hitting } \\
\text { him with a bottle with intent to cause him } \\
\text { grievous bodily harm. [ST1] }\end{array}$} & $\begin{array}{l}\text { O latofatswa ka molato wa go otla ka } \\
\text { maikemisetso a go ntsha dikgobalo tse } \\
\text { di masisi mo mmeleng. Go twe ka di } \\
28 \text { tsa November 2009, gona mo } \\
\text { Nkele's tavern mo Brits, o ile wa otla } \\
\text { ena mongongoregi, wa mo ntsha } \\
\text { dikgobalo tse di masisi mo mmeleng. } \\
\text { A na wa utlwusisa molato o e leng } \\
\text { gore ba go latofatsa ka ona? [TT1] } \\
\text { Backtr: You are charged (+ with an } \\
\text { offence of hitting with the intention of } \\
\text { causing grievous bodily harm. It is } \\
\text { said that) on the } 28^{\text {th }} \text { day of November } \\
2009 \text {, (+ here) at Nkele's tavern in (- } \\
\text { the district of) Brits, you did hit the } \\
\text { complainant (- an adult male person) } \\
\text { and caused him grievous bodily harm. } \\
\text { (+ Do you understand the offence that } \\
\text { you are charged with?) }\end{array}$ & \\
\hline & I do not understand the charge. [TT2] & $\begin{array}{l}\text { A: } \mathrm{Ga} \mathrm{ke} \mathrm{o} \\
\text { thaloganye. [ST2] } \\
\text { Backtr: I do not } \\
\text { understand it. }\end{array}$ \\
\hline & & $\begin{array}{l}\text { A: O tlile mo a re } \\
\text { nna ke mo tlhabile } \\
\text { ka thipa... } \\
\text { (Magistrate } \\
\text { interrupts) [ST3] } \\
\text { Backtr: He came } \\
\text { here and said that I } \\
\text { stabbed him with a } \\
\text { knife... (Magistrate } \\
\text { interrupts) }\end{array}$ \\
\hline
\end{tabular}




\begin{tabular}{|c|c|c|}
\hline Magistrate/Prosecutor/Lawyer/Advocate & Interpreter & Accused/Witness \\
\hline $\begin{array}{l}\text { M: Hey listen. Listen and understand what is } \\
\text { said. Don't tell us what you want us to hear. } \\
\text { You understand? [ST4] }\end{array}$ & $\begin{array}{l}\text { Utlwella ne. O seke wa re tlhalosetsa } \\
\text { se wena o batlang gore rona re se } \\
\text { utlwelle. Utlwella gore rona ra reng. } \\
\text { Ne? O latofatswa ka molato wa go } \\
\text { betha motho ka maikemisetso a go mo } \\
\text { gobatsa mo mmeleng wa gagwe. Ka di } \\
28 \text { tsa November } 2009 \text { ko Nkele's } \\
\text { tavern, gona mo Brits, wena o ile wa } \\
\text { betha mongongoregi, wa mtheta ka } \\
\text { lebotlolo. [TT4] } \\
\text { Backtr: (- Hey) listen. (- Listen and } \\
\text { understand what is said). Do not (- } \\
\text { tell) (+ explain to us) what you want } \\
\text { us to hear. (+ Listen what we are } \\
\text { saying, alright. You are charged with } \\
\text { an offence of hitting a person with an } \\
\text { intention of injuring him on the body. } \\
\text { On the } 28^{\text {th }} \text { of November } 2009 \text {, at } \\
\text { Nkele's tavern, here in Brits, you hit } \\
\text { the complainant; you hit him with a } \\
\text { bottle.) }\end{array}$ & \\
\hline & & $\begin{array}{l}\text { A: Ga ka mmetha... } \\
\text { [ST5] (Magistrate } \\
\text { interrupts) } \\
\text { Backtr: I did not hit } \\
\text { him... (Magistrate } \\
\text { interrupts) }\end{array}$ \\
\hline $\begin{array}{l}\text { M: Do you understand what is being said? } \\
\text { [ST6] }\end{array}$ & $\begin{array}{l}\text { O a thaloganya se ba go bolellang } \\
\text { sona? [TT6] } \\
\text { Backtr: Do you understand what (- is } \\
\text { being said?) (+ they say to you?) }\end{array}$ & \\
\hline & & $\begin{array}{l}\text { A: Wa itse ga ke } \\
\text { thaloganye. [ST7] } \\
\text { Backtr: You know, } \\
\text { I do not understand. }\end{array}$ \\
\hline
\end{tabular}




\begin{tabular}{|l|l|l|}
\hline \multicolumn{1}{|c|}{ Magistrate/Prosecutor/Lawyer/Advocate } & \multicolumn{1}{|c|}{ Interpreter } & Accused/Witness \\
\hline $\begin{array}{l}\text { M: Listen, listen. Either you plead guilty or not } \\
\text { guilty. [ST8] }\end{array}$ & $\begin{array}{l}\text { Utlwella. Bolela gore o ipona molato } \\
\text { kgotsa ga o ipone molato. [TT8] } \\
\text { Backtr: Listen (- listen) (- Either) } \\
\text { Say that) you plead guilty or not. }\end{array}$ & $\begin{array}{l}\text { Not guilty. [TT9] } \\
\text { A: Nna ga ke ipone } \\
\text { Backto. [ST9] }\end{array}$ \\
\hline guilty. I plead not
\end{tabular}

In this case, after interpreting the charge to the accused, the interpreter added "A na wa utlwisisa molato o e leng gore ba go latofatsa ka ona?" ('Do you understand the charge that you are accused of?'). The fact that the interpreter formulated and asked his own question(s) is an indication that interpreters are given latitude. This latitude may allow them to think that they may do as they please, which could result in a miscarriage of justice. In respect of the latitude exercised by the interpreter in case study 2, although the magistrate did not ask this question, the magistrate did not query the interpreter's conduct. Recall that Erasmus (2009; see section 7.1.5.1) notes that it is the task of the magistrate, not the court interpreter, to ask the accused whether s/he understands the charge.

Secondly, the interpreter is interpreting in the second person. There is one instance where the court interpreter says "[...] molato o e leng gore ba go latofatsa ka ona" ("[...] the charge which you are accused of'). In instances such as this, Christensen (2008) mentions that the court interpreter is required to use the direct, first-person style, and notes that this is good interpreting practice. His view is based on the notion that participants must communicate as if the interpreter were not present, and questions and answers should be addressed directly to the person referred to, not to the interpreter.

\subsubsection{Case study 3}

In this case, an unrepresented adult male was charged with an offence of reckless or negligent driving. What appears in Table 3 is what transpired during the proceedings. 
Table 3. Extract for case study 3 (Lebese 2011:353)

\begin{tabular}{|c|c|c|}
\hline Magistrate/Prosecutor/Lawyer/Advocate & Interpreter & Accused/Witness \\
\hline \multirow[t]{4}{*}{$\begin{array}{l}\text { P: You may proceed, take it step by step. } \\
\text { [ST1] }\end{array}$} & $\begin{array}{l}\text { Ja o ka tswelapele wa thalosetsa } \\
\text { lekgotla gore ka lona letsatsi leo go } \\
\text { diragetse eng. O thalose slow gore ba } \\
\text { kgone go kwala dinoutsu, ne? [TT1] } \\
\text { Backtr: (+ Yes) you may proceed (+ } \\
\text { to explain to the court what happened } \\
\text { on that day. You must explain slowly } \\
\text { so that they are able to write notes, } \\
\text { né?) (- take it step by step) }\end{array}$ & \\
\hline & $\begin{array}{l}\text { On that day I was driving on the public } \\
\text { road. I was on my way to work. [TT2] }\end{array}$ & $\begin{array}{l}\text { W: Ka letsatsi leo } \\
\text { ke ne ke tsamaya } \\
\text { mo N4 ke tla } \\
\text { mosebetsing. [ST2] } \\
\text { Backtr: On that day } \\
\text { I was travelling on } \\
\text { the N4 going to } \\
\text { work. }\end{array}$ \\
\hline & $\begin{array}{l}\text { The truck was in front of me. I was } \\
\text { following that truck. [TT3] }\end{array}$ & $\begin{array}{l}\text { W: Ne ke setse } \\
\text { troko morago. } \\
\text { [ST3] } \\
\text { Backtr: I was } \\
\text { following a truck. }\end{array}$ \\
\hline & $\begin{array}{l}\text { And the other truck was behind me. } \\
\text { The truck that was following me. } \\
\text { [TT4] }\end{array}$ & $\begin{array}{l}\text { W: Ga ke ntse ke } \\
\text { latelana le troko eo, } \\
\text { e nngwe e tla ko } \\
\text { morago. [ST4] } \\
\text { Backtr: Whilst I } \\
\text { was following that } \\
\text { truck, the one came } \\
\text { from behind. }\end{array}$ \\
\hline $\begin{array}{l}\text { P: So you know the driver of the truck that } \\
\text { overtook you? [ST5] }\end{array}$ & $\begin{array}{l}\text { A na wa mo itse driver wa truck e e } \\
\text { leng gore e ile ya go overtheika? } \\
\text { [TT5] } \\
\text { Backtr: (- So) (+ Do you) know the } \\
\text { driver of the truck that overtook you? }\end{array}$ & \\
\hline
\end{tabular}




\begin{tabular}{|c|c|c|}
\hline Magistrate/Prosecutor/Lawyer/Advocate & Interpreter & Accused/Witness \\
\hline & & $\begin{array}{l}\text { W: Ee, ke driver e } \\
\text { ka gore ka nako ... } \\
\text { (Interpreter } \\
\text { interrupts) [ST6] } \\
\text { Backtr: Yes, it is } \\
\text { this driver because } \\
\text { at the time ... } \\
\text { (Interpreter } \\
\text { interrupts) [ST2] }\end{array}$ \\
\hline & $\begin{array}{l}\text { (+ Utlwella, Ba go botsa gore a na } \\
\text { driver wa truck e e leng gore e go } \\
\text { overtheikile, wa mo itse driver wa } \\
\text { truck e e leng gore e ile ya go } \\
\text { overtheika?) [ST7] } \\
\text { Backtr: (+ Listen. They ask you if } \\
\text { you) know the driver of the truck that } \\
\text { overtook you, do you know him? }\end{array}$ & \\
\hline & & $\begin{array}{l}\text { W: Ee. [ST8] } \\
\text { Backtr: Yes. }\end{array}$ \\
\hline \multirow[t]{2}{*}{ P: Who is the driver of that truck? [ST9] } & $\begin{array}{l}\text { Ke mang driver wa truck eo? [TT9] } \\
\text { Backtr: Who is the driver of that } \\
\text { truck? }\end{array}$ & \\
\hline & It is Mr Themba. [TT10] & $\begin{array}{l}\text { W: Ke Mr Themba. } \\
\text { [ST10] } \\
\text { Backtr: It is Mr } \\
\text { Themba. }\end{array}$ \\
\hline
\end{tabular}

In this case, the court interpreter adds information in addition to interpreting in the second person. The interpreter says to the witness, "Utlwella. Ba go botsa gore a na driver wa truck e leng gore e go overtheikile, wa mo itse [...]?" ('Listen, they ask you whether you know the driver of the truck that overtook you, do you know him?'). It is not the duty of the interpreter to decide what the witness should say when answering a question, but this seems to be the case in this instance because the interpreter interrupts the witness before he can finish.

Christensen (2008) addresses the issue of the requirement for the use of direct- and first-person style (see section 7.1.5.2 for this discussion); this requirement also applies in the present case study. It is not clear why the interpreter interrupted the witness before the latter could finish saying what he wanted to say. Speculations can be made in this regard, however, they may be true or false as the interpreter involved was not given an opportunity to explain why he interrupted the witness. 
The question can be asked as to whether the interpreter's conduct would have been the same had there been norms by which he had to abide. As mentioned earlier, one of the advantages of norms in court interpreting is that the process of interpreting can be regulated. The answer to the question above would be in the negative on the basis that it is not up to the interpreter to decide what the speaker should (not) say. All participants in court address the presiding officer, be it the judge or the magistrate. The interpreter is not the addressee and therefore does not have the authority to stop the other court participants from saying what they want to say; his/her task is solely to interpret what has been said to the presiding officer.

\section{Discussion of findings}

The findings in this study reveal that the four legal documents investigated do not mention norms which court interpreters have to follow when performing their task of interpreting. The extracts from the court proceedings revealed that there have been instances where court interpreters would ask their own questions, omit certain information, and add information that was never uttered by the speaker. This is an indication that court interpreters work without proper guidance from legislation on how to carry out their task. Such a situation compromises good court-interpreting practice, and may also negatively affect the outcome of the case, which could be detrimental to the accused or the witness who does not speak the language of the record.

As previously mentioned, the PAS is a piece of legislation which regulates the employment, qualification, promotion and salaries of court interpreters, and is a crucial document for court interpreters. This legislation places huge responsibility on court interpreters as guardians of linguistic rights for those who cannot speak the language used during court proceedings. According to the PAS, it is the duty of court interpreters to enable these people to participate fully during court proceedings by facilitating communication between them and other court participants who speak the language of the record. The PAS, however, does not mention any norms which court interpreters have to abide by when they carry out their task. This state of affairs will leave court interpreters in a position where they create and abide by their own individual norms, rather than adhere to common norms of the profession. This was evident in instances where the interpreters asked questions or explained certain things which were supposed to have been asked or explained by magistrates. One would have expected the PAS to have included issues of norms, as discussed above, so as to guide court interpreters in their task and also to protect the users of their service. A situation such as this undermines the rights of those who depend entirely upon court interpreters in order to effectively participate in court proceedings.

Furthermore, the PAS does not make any mention of standards of practice for court interpreters which leads to a situation where there is no proper recruitment of these service providers. The standards of practice could provide clear guidance as regards the desired qualifications, required skills, registration with a body that oversees issues of court interpreters (such as NAJIT in the US), and language proficiency required for the profession.

As stated above, the Magistrates' Court Act regulates the proceedings in the lower courts and defines the duties of various court officials, such as those of the clerk of the court, magistrates and prosecutors. The court officials, whose duties have been clearly and explicitly defined by this Act, are then in a better position to perform their duties as expected. The Act imposes a 
duty on magistrates to provide court interpreters for court participants who cannot understand the language used during court proceedings. However, Section 6(2) does not set out any guidelines for the court interpreters who will be provided by the magistrates. Furthermore, the Act does not set out the qualifications which must be held by these court interpreters, and it does not set out any work-related requirements (for example, language proficiency, membership with a recognised body dealing with court-interpreting issues which also regulates and approves the intake of court interpreters, etc.). One would have expected Section 6(2) of the Act to handle all court-interpreting issues, including defining the role of and the ethics and NSPs for court interpreters.

It is important to point out that the Magistrates' Court Act does not refer to a "court interpreter" but to a "competent interpreter". Interpreters are used in a variety of settings such as hospitals, conferences, churches, police stations, courts, immigration offices, businesses and many others. These interpreters are defined by the setting in which they perform their duties, for example, an interpreter who interprets in a conference setting is called "a conference interpreter", whereas one who interprets in a hospital is called a "healthcare interpreter". The Magistrates' Court Act, however, does not specify to which type of interpreter it refers. It is essential to always refer to interpreters who offer their services in courts as "court interpreters" so as to avoid confusion with other types of interpreter. One needs to bear in mind that different types of interpreters have to be trained differently according to the needs and demands of their work. Conference interpreters, for instance, use simultaneous modes of interpreting, and the training has to be aligned as such. The consecutive mode is mostly used in court interpreting, meaning that court interpreters are trained in this mode as it is primarily used in South African courts. The Act does not define what constitutes a competent interpreter. Consequently, questions that need to be answered include: What makes an interpreter competent? Are there any NSPs for court interpreters which are defined and set out by the Act and which the interpreter must follow at all times in order to be regarded as competent? What measures are used by the court to assess the interpreter as competent? No reason is given in the Act why these issues are not addressed.

The Oath of Office of Interpreters in terms of Rule 68 (1) of the Magistrates' Court Act also does not mention anything regarding norms which court interpreters have to follow during interpreting. The norms should have been included in this oath as clear guidance for court interpreters as to what is expected of them when carrying out their task. The inclusion of norms in the oath would have made it possible for court interpreters to have a clear understanding of the task ahead of them. Furthermore, the inclusion of norms could have been a mechanism of holding interpreters accountable in case they break the oath that they took.

As previously mentioned, the Constitution is regarded as the supreme law of the country. Among other things, it deals with the right of individuals to a fair trial, which encompasses the right of the accused to be tried in a language that s/he understands. Section 35(3)(k) of the Constitution, like Section 6(2) of the Magistrates' Court Act, makes no mention of the court interpreter. It is crucial for the Constitution to deal with all issues relating to court interpreting in this Section, so that the Constitutional Court becomes the arena where disputes relating to court interpreters can be debated and resolved. It is the researcher's view that it is very important for the Constitution to set out, in a very clear manner, all the issues involved in court interpreting, starting with a definition of court interpreting, an explanation of the role of the court interpreter, as well as an elaboration of the NSPs for these court interpreters. The Constitution can even go as far as clarifying vague definitions which appear in the PAS and the 
Magistrates' Court Act. The reason for this is that whatever disputes may arise, the Constitution, as the highest law in the country, would be able to be consulted for clarification of any issue in dispute.

The case studies revealed instances where court interpreters omitted and sometimes added information which was not present in the source language. If court interpreters had clear guidance on how to carry out their task, instances such as these could have been avoided.

\section{Recommendations}

Since the findings in this study have shown the lack of inclusion of NSPs by legislation, the researcher therefore believes it imperative that there should be a statute which deals with issues of court interpreting. The statute should, among others, explicitly set out NSPs as well as address any issues where they are concerned. Another suggestion is for this statute to be included in the PAS, the Magistrates' Court Act and the South African Constitution. The statute could be termed the "South African Court Interpreters Act" (SACIA), and may be divided into different sections and subsections dealing with issues pertaining to recruitment, qualifications, training, role definition, accreditation, registration of practitioners, NSPs in court interpreting (dealing with complaints relating to misinterpretation, appeal procedures, and sanctions), as well as the code of conduct. The SACIA would serve as a regulatory mechanism for the profession of court interpreting, protecting the rights of both the user and provider of courtinterpreting services, and would clarify issues that seem unclear in relation to the profession and its practices.

The NSPs contained in the SACIA would ensure that, before they are employed, court interpreters have the required linguistic competence and that they are fluent in the languages in which they state they are able to work. The norms could be termed "Court Interpreting Norms in the South African Courts", and, in accordance with Chesterman (1997), would be divided into three categories: accountability norms, communication norms and relation norms. The accountability norm would deal with professional standards of integrity and thoroughness, ensuring that court interpreters accept responsibility for their product (the interpreted message). The communication norm would ensure that the listener receives an interpretation that is clear and understandable. Finally, the relation norm would ensure that the interpreted message received by the listener matches the source-language message.

Court interpreters should be sensitised to these NSPs even before they start interpreting in any court. The statute should further remove any uncertainties and conflicting views pertaining to the role of court interpreters (see Lebese 2011, 2013). Such legislation will lead to the legal recognition of court interpreters and their services, and thus to a better quality interpreting service in the country which will ultimately benefit all its citizens. The creation of this legislation would serve justice to court interpreters upon whom the freedom of accused persons rests. This would be the first step in laying a foundation for professionalising court interpreting in South Africa, and would aid in resolving the complexities surrounding court interpreters and the service they provide.

The researcher further believes that it is crucial for the legal profession to work together with experienced court interpreters, researchers and scholars - from the fields of Linguistics, Law 
and Communication Studies - to develop a body of knowledge on court interpreting that would deal with issues pertaining to the profession.

\section{Conclusion}

The aim of this study was to investigate whether or not the statement by Judge Williamson was true. This aim was achieved by investigating the four legal documents relating to court interpreters, and by analysing the extracts from court proceedings. The findings revealed that the four pieces of legislation investigated did not mention anything regarding NSPs for court interpreters. The literature review has shown that translation, in its broadest sense (encompassing the concept of 'interpreting'), is a process involving interaction between people, and therefore norms play a very important role because they have a regulatory function (Hjort 1992). Because court interpreting involves interaction between people speaking different languages, norms would apply to the process.

Several extracts from court proceedings were also analysed to observe how court interpreters carried out their task during the proceedings. The analyses of these proceedings have shown that there were instances where court interpreters would ask their own questions, omit information and, at times, add information that the speaker did not mention. Conduct such as this could have repercussions for the people receiving the interpreting services.

The findings in this study reveal the need for the creation of a statute on court interpreting, which could be divided into different sections and subsections. The statute could be called the "South African Court Interpreters Act", and would operate as a controlling measure, dealing with court-interpreting issues relating to recruitment methods, qualifications, training, role definition, accreditation, registration, and also issues of NSPs that all court interpreters have to observe. The norms will enable a better understanding and a clear definition of the role of court interpreters as this role is not clearly defined (see Lebese 2011, 2013). The standards of practice will ensure that the Department of Justice and Constitutional Development recruits candidates who possess the required qualifications and the necessary skills to meet the demands of the profession.

\section{References}

Baker, P.W.E., H.J. Erasmus and I.G. Farlam. 1980. Handbook on the magistrates' courts act and rules. Cape Town/Johannesburg: Juta.

Bartsch, R. 1987. Norms of language: Theoretical and practical aspects. London/New York: Longman.

Camayd-Freixas, E. 2011. Interpreting in a changing landscape. Proceedings of the $6^{\text {th }}$ International Critical Link Conference. Amsterdam and Philadelphia: John Benjamins.

Chesterman, A. 1997. Memes of translation. The spread of ideas in translation theory. Amsterdam and Philadelphia: John Benjamins. 
Christensen, T.P. 2008. Judges' deviations from norm-based direct speech in court. Interpreting 10(1): 99-127.

Danish Administration of Justice Act XI of 1994, as amended by Legal Notice 425 of 2007.

Duflou, V. 2007. Norm research in conference interpreting: How can the study of documentary sources contribute to a better understanding of norms? In H. Gerzymisch-Arbogast and G. Budin (eds.) LSP translation scenarios: Proceedings of the Marie Curie Euroconferences MuTra: LSP Translation Scenarios, 30 April-4 May, Vienna.

De Jongh, E.M. 2008. Court interpreting: Linguistic presence v. linguistic absence. Florida Bar Journal 82(7): 21-32.

Du Plessis, L.T. (ed.) 1997. Onderweg na vertaal- en tolkopleiding in Suid-Afrika. Acta Varia 1997(3): Bloemfontein: University of the Orange Free State. pp. 1-9.

Erasmus, D. 2009. Procedural explanations and choices: The undefended accused in a minefield. Law, Democracy and Development 13(1): 13-39.

Gall, M.D., W.R. Borg and J.P. Gall. 1996. Educational research. White Plains, NY: Longman.

González, R.D., V.F. Vasquez and H. Mikkelson. 1991. Fundamentals of court interpreting: Theory, policy and practice. Durham, NC: Carolina Academic Press.

Hermans, T. 1996. Norms and the determination of translation: A theoretical framework. In R. Álvarez and C.Á. Vidal (eds.) Translation, power, subversion. Clevedon, UK: Multilingual Matters. pp. 25-51.

Hermans, T. 2013. Norms of translation. In C.A. Chapelle (ed.) The encyclopedia of applied linguistics. Chichester: Wiley Blackwell. pp. 4262-4268.

Hewitt, W. 1995. Court interpretation: Model guides for policy and practice in the state courts. Williamsburg, VA: National Center for State Courts.

Hillinger, M. and D.J. Leu. 1994. Guiding instruction in hypermedia. Proceedings of the Human Factors and Ergonomics Society Annual Meeting October 1994: 266-270.

Hjort, P.F. 1992. Prioritization from philosophy to praxis. The Journal of Medicine and Philosophy 69: 318-326.

Hlophe, J.M. 2004. Receiving justice in your own language - The need for effective court interpreting in our multilingual society. Advocate 17(1): 42-47.

Keratsa, A. 2005. Court interpreting: features, conflicts and the future. Available online: http://www.translatum.gr/journal/5/court-interpreting.html (Accessed 28 November 2005).

Lebese, S. 2011. A pilot study on the undefined role of court interpreters in South Africa. Southern African Linguistics and Applied Language Studies 29(3): 343-353. 
Lebese, S. 2013. The undefined role of court interpreters in South Africa. MA dissertation. Pretoria: University of South Africa.

Magistrates' Court Act 44 of 1944 (as amended). 1994. In P.W.E. Baker, H.J. Erasmus and I.G. Farlam. 1980. Handbook on the magistrates' courts act and rules. Cape Town/Johannesburg: Juta.

Malmkjaer, K. 2005. Norms and nature in translation studies. SYNAPS 16: 13-19.

Meulenberg-Buskens, I. 1993. Introduction. In Course material for the qualitative methodology summer school. Pretoria: HCRC.

Meulenbergs, T., E. Verpeet, P. Schotsmans and C. Gastmans. 2004. Professional codes in a changing nursing context: literature review. Journal of Advanced Nursing 46(3): 331-336.

Meylaerts, R. 2008. Translators and (their) norms: Towards a sociological construction of the individual. In A. Pym, M. Shlesinger and D. Simeoni (eds.) Beyond descriptive translation studies: Investigation in homage to Gideon Tour. Amsterdam/Philadelphia: John Benjamins. pp. 91-102.

Mikkelson, H. 1996. The professionalization of community interpreters. In J.-O'Keeffe (ed.) Global vision. Alexander, Virginia: American Translators Association. pp. 77-89.

Mikkelson, H. 2008. Evolving views of the court interpreter's role: Between Scylla and Charybdis. In C. Valero-Garcés and A. Martins (eds.) Crossing borders in community interpreting: Definitions and dilemmas. Amsterdam: John Benjamins. pp. 81-98.

Munday, J. 2008. Introducing translation studies. London: Routledge.

National Association of Judiciary Interpreters and Translators (NAJIT). 2005. Code of ethics and professional responsibilities. Available online: http://www.najit.org/ethics.html (Accessed 20 December 2005).

Oath of Office of Interpreters Rule 68 (1).

Personnel Administration Standard for Court Interpreters (PAS) (HOFTLK 97).

Pöchhacker, F. and M. Shlesinger. (eds.) 2002. The interpreting studies reader. London; Routledge.

Schäffner, C. 1998. Translation and quality. Clevedon/Philadelphia: Multilingual Matters.

Shank, G.D. 2002. Qualitative research: A personal skills approach. Upper Saddle River, New Jersey: Prentice Hall.

State versus Naidoo. 1962. In J. Hoexter, G. Duncan, M. Barnett and B.A. Buchanan (eds.) The South African Law Reports 1962(2). Cape Town: Juta. 
Republic of South Africa (RSA). 1996. The Constitution of the Republic of South Africa, 1996. Act 108 of 1996. Pretoria: Government Printers.

Toury, G. 1980. In search of a theory of translation. Jerusalem: Academic Press.

Toury, G. (ed.) 1995. Descriptive translation studies and beyond. Amsterdam and Philadelphia: John Benjamins.

Tseng, J. 1992. Interpreting as an emerging profession in Taiwan - A sociological model. Unpublished Masters thesis. Taiwan: Fu Jen Catholic University. 